\title{
Bone marrow mononuclear cells and acute myocardial infarction
}

\author{
Samer Arnous', Abdul Mozid', John Martin' and Anthony Mathur*
}

\begin{abstract}
Stem cell transplantation is emerging as a potential therapy to treat heart diseases. Promising results from early animal studies led to an explosion of small, non-controlled clinical trials that created even further excitement by showing that stem cell transplantation improved left ventricular systolic function and enhanced remodelling. However, the specific mechanisms by which these cells improve heart function remain largely unknown. A large variety of cell types have been considered to possess the regenerative ability needed to repair the damaged heart. One of the most studied cell types is the bone marrow-derived mononuclear cells and these form the focus of this review. This review article aims to provide an overview of their use in the setting of acute myocardial infarction, the challenges it faces and the future of stem cell therapy in heart disease.
\end{abstract}

\section{Introduction}

Despite the recent advances in percutaneous intervention, drug and device therapy, patients with acute myocardial infarction (AMI) and resulting left ventricular impairment have $13 \%$ mortality at 1 year [1]. Following the loss of over one billion cardiomyocytes in a functionally significant MI, the overloaded surviving cardiomyocytes undergo abnormal remodelling, eventually leading to heart failure. This condition, a leading cause of death and disability in the developed world, is associated with 5 -year mortality rates of up to $70 \%$ in symptomatic patients [2]. Current conventional therapies do not correct underlying defects in cardiac muscle cell number [3].

The only therapeutic option that currently addresses cardiomyocyte loss is heart transplantation. However,

\footnotetext{
*Correspondence: a.mathur@gmul.ac.uk

2Department of Cardiology, London Chest Hospital, Queen Mary University of London, Barts and the London NHS Trust, Bonner Road, London E2 9JX, UK Full list of author information is available at the end of the article
}

due to stringent selection criteria and chronic shortage of donor hearts, the vast majority of patients are deemed unsuitable or never receive a transplant. Therefore, preventing this progression post-MI is a major challenge requiring novel therapeutic strategies such as stem cell transplantation to improve the prognosis and quality of life for these patients.

The traditional view that the heart is a terminally differentiated organ has been challenged by the discovery of differentiation of stem cells into cardiomyocytes in animal and human hearts [4-7]. This in turn has led to the exciting possibility for regenerative therapy for cardiomyocyte loss after a MI. The demonstration of functional recovery of myocardium through cardiomyogenesis and neoangiogenesis in AMI in murine models by Orlic and colleagues [8] generated tremendous interest in the potential of bone marrow-derived stem cells. Since then, the cardiomyogenic ability of these cells has been challenged. However, studies continue to demonstrate improvement in cardiac function and reduction in infarct size. It should be noted that progenitor cells also contribute to cardiac repair by mechanisms beyond the growth of new cardiomyocytes and as such may offer an 'indirect' benefit.

\section{Animal and human trials}

The most promising and obvious cell type for the growth of new cardiomyocytes is the embryonic stem cell; however, considerable technical and ethical issues exist with these cells, which must be overcome before their successful use in humans. Adult stem cells are an attractive option to explore for transplantation as they are autologous, but their differentiation potential is more restricted than embryonic stem cells. Currently, the major sources of adult cells used for basic research and in clinical trials originate from the bone marrow. The bone marrow mononuclear subset is heterogeneous and comprises mesenchymal stem cells, haematopoietic progenitor cells and endothelial progenitor cells. The differentiation capacity of different populations of bone marrow-derived stem cells into cardiomyocytes has been studied intensively. The results are rather confusing and difficult to compare, since different isolation and identification 
methods have been used to determine the cell population studied. To date, only mesenchymal stem cells seem to form cardiomyocytes, and only a small percentage of this population will do so in vitro or in vivo. Pragmatically, the translation of the basic science into clinical research has followed a common pathway: injection of bone marrow-derived mononuclear cells (BMMNCs) as a source of stem cells into the heart. Table 1 provides a summary of clinical trials using BMMNCs in patients with acute MI.

\section{Trials with no sham bone marrow harvest or intracoronary} re-infusion in the control group

In the first human trial, Strauer and colleagues [9] reinfused intracoronary BMMNCs 7 days after myocardial infarction (MI). The mean number of mononuclear cells was $2.8 \times 10^{7}$. There was a significant improvement in myocardial perfusion and a reduction in the infarct region in the cell therapy group. The Transplantation of Progenitor Cells and Regeneration Enhancement in Acute Myocardial Infarction (TOPCARE-AMI) investigators randomised patients into intracoronary infusion of BMMNCs or ex vivo expanded circulating progenitor cells 4 days after MI [10]. There was a significant improvement in global and regional left ventricular (LV) function in both groups and a beneficial effect on the post-infarction remodelling process manifest by a profound improvement in wall motion abnormalities in the infarct area and a significant reduction in end-systolic $\mathrm{LV}$ volume at 4 months post-MI. The LV ejection fraction (LVEF) further improved at 12 months, resulting in a total increase of $9.3 \%$ at 1 year [11]. Of interest, there was no difference between the two active treatment groups. The mean number of infused cells was $245 \times 10^{6}$, which contained haematopoietic progenitor, mesenchymal and stromal cells. However, a major limitation of both of these trials was the lack of a control group receiving sham bone marrow harvest or intracoronary re-infusion.

Another trial in which there was no sham procedure is the Autologous Stem-Cell Transplantation in Acute Myocardial Infarction (ASTAMI) trial, which included only patients with acute anterior MI. The intracoronary re-infusion of BMMNCs 4 to 8 days after infarction did not have a beneficial effect on LVEF compared to percutaneous coronary intervention (PCI) alone at 6 months [12]. This lack of beneficial effect may be explained by the different cell processing protocols used in this trial. Cell processing protocols may have a significant impact on the functional capacity of bone marrow-derived stem cells [13]. Comparison of different isolation protocols revealed a vastly reduced recovery of mononuclear cells and nullification of the neovascularisation capacity when the ASTAMI cell isolation and storage protocol was used [13].
The Bone Marrow Transfer to Enhance ST-Elevation Infarct Regeneration (BOOST) trial, a slightly larger trial, included 60 patients that were randomised to receive intracoronary BMMNCs or standard therapy 4.8 days after successful PCI following AMI. There was a significant improvement in global LVEF in the cell treatment group at 6 months without an effect on LV remodelling [14]. However, this improvement was not maintained at 18 months. The mean number of bone marrow cells that were infused contained $9.5 \times 10^{6} \mathrm{CD}^{2} 4^{+}$and $3.6 \times 10^{6}$ haematopoietic colony-forming cells. The improvement in LVEF did not correlate with the number of CD34+ cells or haematopoietic colony forming cells. Again, a major limitation of the BOOST trial is that the control group did not undergo a sham bone marrow harvest or intracoronary infusion.

The first long-term study involving 62 patients who underwent intracoronary BMMNC transplantation 7 days post-AMI not only resulted in an early significant improvement in ejection fraction (EF) and infarct size, but there was also a significant reduction in mortality and improvement in exercise capacity compared to controls at 5 years [15].

\section{Randomised controlled trials}

The Transcatheter Transplantation of Stem Cells for Treatment of Acute Myocardial Infarction (TCT-STAMI) trial, which included a control group receiving a placebo infusion, showed a significant (approximately 5\%) improvement in LVEF of patients receiving intracoronary BMMNCs at 6 months [16].

Intracoronary bone marrow derived progenitor cells in acute infarction (REPAIR-AMI), a large randomized double-blind controlled trial that included over 200 patients, showed an improvement in the primary endpoint in the treatment group that was an absolute change in global LVEF from baseline to 4 months, as measured by quantitative left ventricular angiography [17]. Furthermore, the pre-specified cumulative endpoint of death, MI, or revascularisation was significantly reduced, and this benefit was maintained at one year follow-up [18]. The mean increase in LVEF in the BMMNC group was $2.5 \%$ and there was an inverse relationship between the baseline EF and the degree of improvement. For example, patients with a baseline EF below the median value (48.9\%) had an absolute increase in global EF that was three times higher than that in the placebo group. In contrast, the improvement in LVEF in patients with a baseline EF that was above the median value was non-significant $(0.3 \%)$. The timing of cell infusion post-PCI also had an effect on the primary endpoint. Patients in whom the cells were infused $\geq 5$ days post-PCI were the only ones who derived benefit. 
Table 1. Clinical trials using autologous bone marrow mononuclear cells in patients with acute myocardial infarction

\begin{tabular}{|c|c|c|c|c|c|c|}
\hline Study & $\begin{array}{l}\text { Study } \\
\text { design }\end{array}$ & $\begin{array}{l}\text { Cell } \\
\text { type }\end{array}$ & $\begin{array}{l}\text { Delivery } \\
\text { method }\end{array}$ & $\underset{\text { Timing }}{\text { post-infarction }}$ & $\begin{array}{l}\text { Adjunct } \\
\text { procedure }\end{array}$ & Outcome \\
\hline Meluzin et al. [93] & RCT & BMMNC & IC & 5-9 days & $\mathrm{PCl}$ & $\begin{array}{l}\text { Dose-dependent improvement of regional myocardial } \\
\text { function by PET }\end{array}$ \\
\hline Fernandez-Aviles et al. [94] & NR & BMMNC & IC & $13.5 \pm 5.5$ days & $\mathrm{PCl}$ & $\begin{array}{l}\text { Decrease in end systolic volume, improvement in regional } \\
\text { and global function }\end{array}$ \\
\hline Janssens et al. [19] & RCT & BMMNC & IC & 1 day & $\mathrm{PCl}$ & $\begin{array}{l}\text { No effect on global LVEF, but may favourably affect infarct } \\
\text { remodelling }\end{array}$ \\
\hline Lunde et al. [12] (ASTAMI) & RCT & BMMNC & IC & 6 days & $\mathrm{PCl}$ & No effect on global LVEF \\
\hline $\begin{array}{l}\text { Schächinger et al. [17] } \\
\text { (REPAIR-AMI) }\end{array}$ & RCT & BMMNC & IC & 3-7 days & $\mathrm{PCl}$ & Improvement in global LVEF \\
\hline Ge et al. [16] & RCT & BMMNC & IC & Immediately & $\mathrm{PCl}$ & Improvement in LVEF \\
\hline De Lezo et al. [95] & RCT & $\begin{array}{l}\text { BMMNC } \\
\text { or GCSF }\end{array}$ & IC & 7 days & $\begin{array}{c}\text { IV } \\
\text { fibrinolytics } \\
+P C l\end{array}$ & Improvement in LVEF \\
\hline Zhan-quan et al. [96] & NRC & PBSC & IC & 6 days & $\mathrm{PCl}$ & Improvement in LVEF \\
\hline Wollert et al. [14] (BOOST) & $\mathrm{RCT}$ & BMMNC & IC & 4.8 days & $\mathrm{PCl}$ & Improvement in LV systolic function \\
\hline Lipiec et al. [97] & RCT & BMMNC & IC & 4-11 days & $\mathrm{PCl}$ & $\begin{array}{l}\text { Improvement in myocardial perfusion with no effect on } \\
\text { global LVEF }\end{array}$ \\
\hline $\begin{array}{l}\text { Huikuri et al. [98] } \\
\text { (FINCELL) }\end{array}$ & RCT & BMMNC & IC & 2-6 days & $\begin{array}{c}\text { IV } \\
\text { thrombolysis } \\
+\mathrm{PCl}\end{array}$ & Improvement in global LVEF \\
\hline Kang et al. [99] & RCT & $\begin{array}{l}\text { PBSC } \\
\text { and GCSF }\end{array}$ & IC & & $\mathrm{PCl}$ & $\begin{array}{l}\text { Improvement in myocardial perfusion and systolic } \\
\text { function }\end{array}$ \\
\hline $\begin{array}{l}\text { Assmus et al. [10] } \\
\text { (TOPCARE-AMI) }\end{array}$ & NR & $\begin{array}{l}\text { BMMNC } \\
\text { or CPC }\end{array}$ & IC & 3-7 days & $\mathrm{PCl}$ & Improvement in LVEF \\
\hline $\begin{array}{l}\text { Schächinger et al. [11] } \\
\text { (TOPCARE-AMI) }\end{array}$ & NR & $\begin{array}{l}\text { BMMNC } \\
\text { or CPC }\end{array}$ & IC & 3-7 days & $\mathrm{PCl}$ & Improvement in $\mathrm{EF}$ \\
\hline Strauer et al. [9] & NRC & BMMNC & IC & 5-9 days & $\mathrm{PCl}$ & Reduction in infarct region \\
\hline Bartunek et al. [100] & NRC & BMMNC (CD133) & IC & 11.6 days & $\mathrm{PCl}$ & Improvement in LVEF \\
\hline Hirsch et al. [21] & RCT & BMMNC & IC & 3-8 days & $\mathrm{PCl}$ & No effect on global or regional LV function \\
\hline Tendera et al. [20] & RCT & BMMNC & IC & 3-12 days & $\mathrm{PCl}$ & No significant improvement in LVEF \\
\hline Chen et al. [101] & RCT & BMMNC & IC & 18 days & $\mathrm{PCl}$ & Improvement in LVEF \\
\hline Yousef et al. [15] (BALANCE) & NRC & BMMNC & IC & 7 days & $\mathrm{PCl}$ & Improvement in LVEF, exercise capacity and mortality \\
\hline
\end{tabular}

Time from myocardial infarction to transplantation and outcomes measured are listed. ASTAMI, Autologous Stem-Cell Transplantation in Acute Myocardial Infarction; BMMNC, bone marrow-derived mononuclear cell; BOOST, Bone Marrow Transfer to Enhance ST-Elevation Infarct Regeneration; CPC, circulating progenitor cell; EF, ejection fraction; GCSF, granulocyte-colony stimulating factor; IC, intracoronary; IM, intramyocardial; LVEF, left ventricular ejection fraction; NR, non-randomised; NRC, non-randomised with control group; PBSC, peripheral blood stem cell; PCl, percutaneous coronary intervention; PET, positron emission tomography; RCT, randomised controlled trial; REPAIR-AMI, Reinfusion of Enriched Progenitor Cells and Infarct Remodeling in Acute Myocardial Infarction; TOPCARE-AMI, Transplantation of

Progenitor Cells and Regeneration Enhancement in Acute Myocardial Infarction.

By contrast, the LEUVEN-AMI study by Janssens and colleagues [19] showed that intracoronary re-infusion of BMMNCs within 24 hours of reperfusion was associated with a greater reduction in infarct size and improved regional systolic function, but no overall improvement in global left ventricular function compared to controls.

Trials that used two different cell populations

More recently, the Myocardial Regeneration by Intracoronary Infusion of Selected Population of Stem Cells in Acute Myocardial Infarction (REGENT) trial, which included patients with anterior MI, uniquely compared two cell types. Patients were randomized to receive intracoronary infusion of unselected $(n=80)$ or selected $\mathrm{CD}{ }^{+}{ }^{+} \mathrm{CXCR}^{+}{ }^{+}(\mathrm{n}=80)$ BMMNCs, or to the control group $(n=40)$ [20]. Although patients in the treatment group had a $3 \%$ improvement in LVEF, this did not reach statistical significance. However, the primary endpoint analysis included $<60 \%$ of the total population of patients, which is likely to be responsible for the failure in the improvement in LVEF to achieve statistical significance. Subgroup analysis showed that baseline EF below the median value (37\%) was an independent predictor of significant $(\geq 5 \%)$ increase in LVEF after treatment with BMMNCs. 
The HEBE trial compared the intracoronary infusion of BMMNCs or mononuclear peripheral blood cells to standard therapy alone following an AMI [21]. The intracoronary BMMNCs were delivered between 3 to 8 days after AMI. They showed no effect of either treatment on regional or global left ventricular function.

\section{Benefits beyond ejection fraction}

A recent comprehensive systematic review that included 13 trials with a total of 811 patients showed an improvement in LVEF by $2.99 \%$ in the BMMNC group compared to standard reperfusion therapy [22].

A previous meta-analysis by Lipinski and colleagues [23] that included 10 trials with AMI showed that intracoronary stem cell therapy (within the first 14 days after infarction) was associated with a small but significant (3.0\%) improvement in LV systolic function compared to standard medical therapy. It was also associated with a non-significant reduction in death and rehospitalisation from heart failure. Although they found no significant association between the benefits of intracoronary cell injection and the number of injected cells, there was a trend toward a statistically significant association with the injected volume, suggesting the possible presence of a dose-response relationship. The improvement in LVEF was observed in both bone marrow and peripheral mononuclear cells. Similar conclusions were reached in the meta-analysis by Abdel-Latif and colleagues [24], which included 18 studies and showed that stem cell therapy significantly increased LVEF by $3.66 \%$.

In contrast to animal models, the improvement in LV function in most clinical trials is at best modest. However, it should be noted that several of our established therapies that have an impact on prognosis in patients with MI and a reduced LV function, such as angiotensin-converting enzyme inhibitors, $\beta$-blockers [25], thrombolytic therapy and percutaneous coronary intervention [26,27], are associated with similar improvements in LVEF. It is likely that adult stem cells exert their benefit on cardiac remodelling through an 'indirect' paracrine effect, and that the small functional benefit seen with this therapy may translate into significant long-term improvement in exercise tolerance and survival [15].

The main surrogate markers used as an end-point have been EF and perfusion defects, which correlate poorly with prognosis and quality of life $[28,29]$. Therefore, in the future, the validation of progenitor cell therapy for clinical use may depend on the demonstration of a benefit with regard to clinical outcomes such as improvement in prognosis, quality of life [30], New York Heart Association functional classification and exercise capacity.

\section{The debated hypothesis}

The divergent findings from current trials may be due to several factors. There appears to be an inverse relationship between the benefit seen with stem/progenitor cell therapy and the baseline LV function, with cell therapy being most effective in patients with a lower LVEF $[17,20]$. Furthermore, patients with longer ischaemic time ( $>5$ hours) may be more likely to have significant improvement of LVEF following the BMMNC infusion [20].

The timing of cell infusion may also play a role on the derived benefit. Although the REPAIR-AMI trial suggests that the enhanced improvement of the LVEF was confined to patients who were treated $\geq 5$ days after primary PCI, the investigators of the HEBE and REGENT trials showed no interaction between the timing of cell infusion and derived benefit. The meta-analysis by MartinRendon and colleagues [22], however, showed that the benefit of stem cell therapy was even greater when the BMMNCs were infused $>7$ days after MI. The effect of timing on the beneficial effects of BMMNC administration is further supported by the study by Lai and colleagues [31] that showed that intracoronary BMMNC administration provided cardio-protection in a fashion similar to ishaemic preconditioning. This benefit was only seen when the myocardium had not been preconditioned by other means. An ongoing study at our centre, the REGENERATE-AMI (ClinicalTrial.gov NCT00765453), is designed to study the delivery of BMMNCs at very early time points (within 6 hours of PCI). The purpose of this design is to replicate the animal models where very early interventions lead to a significant (40\%) improvement in cardiac function [8].

The dose of infused BMMNCs has varied between different trials with variable results. There appears to be a dose-dependent improvement in EF, with the benefit of BMMNCs only seen when doses higher than $10^{8}$ are administered [22].

\section{Direct (transdifferentiation) and indirect (paracrine and angiogenesis) effects of stem cells}

To date, there is no direct clinical evidence that cellular cardiomyogenesis in fact occurs in the human heart after transplantation of progenitor cells, and over the past few years, various experiments using different types of stem cells have shown that $<2 \%$ of the transplanted cells transdifferentiate into cardiomyocytes [32]. Therefore, the number of cardiac cells produced by cardiac regeneration alone is unlikely to explain the effects seen. In experiments using a mouse model of MI, bone marrow-derived cells were shown to undergo a very low level of transdifferentiation into cardiomyocytes and most of these cells continued to differentiate along the haematopoietic lineage $[33,34]$. However, engraftment of these haematopoietic 
cells at the infarct site led to an improvement in myocardial function that is likely attributed to vasculogenesis, angiogenesis and a paracrine effect. Adult stem cells secrete a variety of cytokines, chemokines, and growth factors that are involved in cardiac repair [35] and the production of these factors is increased in response to the hypoxic stress associated with AMI [36]. Takahashi and colleagues [37] showed that BMMNCs in rats produce and release various cytoprotective factors, including vascular endothelial growth factor, platelet-derived growth factor, interleukin-1 $\beta$, and insulin-like growth factor-1, some of which are significantly up-regulated by hypoxia. These paracrine factors may influence adjacent cells and exert their actions via several mechanisms, including myocardial protection and neovascularisation. Furthermore, in humans, direct injection of BMMNCs during acute ischaemia results in a direct cardioprotective effect, by abolishing the process of apoptosis and necrosis [38], which in part explains the clinical benefit seen in clinical trials. This cardioprotective mechanism appears to be dose related with the benefit only seen with injected doses that are $\geq 5 \times 10^{6}$.

Neo-angiogenesis in the peri-infarct zone is an integral part of the cardiac remodelling process [39]. Under normal circumstances, however, this is seldom sufficient to meet the demands of the hypertrophied myocardium, and the compensatory tissue growth required for myocardial contractility. One of the therapeutic advantages of bone marrow-derived cells is to induce therapeutic angiogenesis in ischaemic tissues, which in turn would augment oxygen supply [40-43], and help rescue cells from critical ischaemia [44]. Dowell and colleagues [45] have shown with histological examination at 2 weeks postinfarction that injection of $\mathrm{CD}_{3} 4^{+}$cells was accompanied by a significant increase in infarct zone microvascularity, cellularity and fibrosis in comparison to controls. They also showed that neoangiogenesis was increased within both the infarct zone and the peri-infarct rim in rats receiving $\mathrm{CD} 4^{+}$cells compared with saline controls [45].

Paracrine factors released by transplanted stem cells may alter the extracellular matrix, resulting in more favourable post-infarction remodelling and strengthening of the infarct scar. In animal models of MI, the injection of endothelial progenitor cells or bone marrow-derived stem cells significantly improved blood flow and cardiac function and reduced left ventricular scarring [46,47]. After an ischaemic event, the efficiency of engrafment differs between different progenitor subpopulations $[48,49]$. The formation of new blood vessels occurs as a result of the interaction of different types of stem cells with cardiomyocytes [46,50-53]. Neovascularisation is mediated by the physical integration of progenitor cells into new capillaries $[48,54]$, or through a paracrine effect by releasing growth factors that promote angiogenesis
[55], depending on the cell type and the circumstances of the cardiac injury.

\section{Route of cell administration}

The three routes of stem cell delivery that have been used so far in clinical trials are through intracoronary or intramyocardial injection or peripherally through the systemic circulation. It is not yet possible on the basis of existing clinical studies to assert a 'best' mode of delivery. However, it is likely that patients' individual pathobiology as well as the aetiology of their cardiac dysfunction will ultimately dictate the route chosen among potential progenitor cell therapies. The advantage of intracoronary delivery is that cells are directly injected into areas of good blood supply rich in nutrients and oxygen, which is essential for cell survival. Myocardial ischemia is a major stimulus for incorporation of circulating progenitor cells, and potently up-regulates the chemo-attractants for neoangiogenesis. Even after infarction, however, the absolute number of progenitor cells detected in the heart is very low $[40,41,56,57]$, but intracoronary infusion of progenitor cells may enhance local accumulation and homing compared to intravenous injection.

By contrast, the benefit of direct intramyocardial cell delivery into hibernating myocardium is that it negates the need for the uptake of progenitor cells from the circulation. Electromechanical (NOGA) mapping is essential to ensure that the cells are injected in areas of hibernating myocardium [58], as necrotic areas of myocardium and scar tissue lack the necessary cues for cells to engraft and differentiate, and cells injected in these areas die immediately [59].

\section{Homing}

While homing of haematopoietic progenitor cells to bone marrow has been widely studied [60], the mechanisms of homing of progenitor cells to areas of tissue injury remain poorly understood. Homing is a complex process involving integrins and chemokine receptors, which is greatly enhanced after myocardial ischaemia and hypoxia. It includes adhesion to and transmigration through the endothelium followed by migration and invasion of the target tissue. Homing of cells is dependent on migration out of the vessel into the surrounding myocardium; therefore, underperfused regions of the myocardium are targeted in a less efficient manner [61]. The two key factors that play an important role in homing after a MI are the release of stromal-cell-derived factor (SDF)-1 and a chromatin binding protein (HMGB1). SDF-1 regulates homing of stem cells to ischaemic tissue through integrin-dependent adhesion [62-64], and local delivery of SDF-1 can enhance progenitor cell recruitment and neovascularisation $[65,66]$. The release of HMGB1 may act as a danger signal and stimulate the homing of stem cells to ischaemic tissue [67]. 
Furthermore, endothelial progenitor cells express a number of chemokine receptors, such as CXCR2, CXCR4 and CXCL12. These chemokines play an important role in the homing and mobilisation of endothelial progenitor cells and their recruitment to the site of ischaemic injury for endothelial recovery [68-71].

\section{Where is research in this area heading in the next few years?}

The need for new therapies to treat patients with AMI has led to a swift transition from bench to bedside and a number of clinical trials showing promising potential for stem cell therapy in heart disease. The ultimate aim of this research is to develop a technique that grows new functioning heart muscle. However, many obstacles still lie ahead. One of the many remaining unanswered questions is which type of stem/progenitor cell is the best candidate for cardiac regeneration. The bone marrow is an attractive source because it is easily accessible and contains a number of stem cells, including haematopoietic and mesenchymal cells. It is likely, however, that bone marrow cells in humans work through an indirect paracrine mechanism. The safety and feasibility of bone marrow cells in AMI have been well established in clinical trials. This, therefore, supports the need for robust evidence from large double-blind randomised controlled trials to assess their effect on clinical endpoints such as mortality and symptoms.

The European Society of Cardiology established a task force to investigate the role of stem cells in cardiac repair and published its consensus in a 2006 report [72]. The future focus in stem cell therapy should be to provide a better understanding of the mechanism of functional improvements observed and the development of safe and effective cell tracking modalities. These areas of research would aid the identification of the best cell candidate for therapeutic use as well as better understanding of myocardial homing and cell survival post-transplantation. It is important to note, however, that the clinical experience has provided a lot of valuable information regarding the approaches to cell therapy in humans, which will of course provide a platform for future trials in this field.

One of the challenges in the future is improving the durability and survival of stem cells in the adverse environment they are engrafted into. One of the properties of stem cells is stress resistance [73], although several studies have shown that most stem cells die within a few weeks of delivery into the myocardium [34,74-76]. This is probably due to the lack of nutrients and oxygen within the ischaemic environment. Furthermore, heart failure [77], atherosclerosis [78,79] and advanced age [80,81] correlate inversely with the number and function of circulating endothelial progenitor cells. Allogenic cells from young and healthy donors may represent a good solution, but cell rejection requiring immunosuppressive therapies would pose a new problem. There is some evidence that statins improve the survival of the circulating endothelial progenitor cells $[82,83]$. Furthermore, higher doses of statin therapy are associated with a greater increase in circulating $\mathrm{CD}_{3} 4^{+}$and $\mathrm{CXCR} 4^{+}$from the bone marrow, resulting in an increase in coronary flow reserve at 8 months [84]. Future trials are on the horizon assessing the role of statin therapy on enhancing the number of endothelial cells in patients with coronary artery disease (Clinicaltrials.gov CT01096875). Endothelial progenitor cells are a subset of haematopoietic cells that have an important role to play in ischaemia by promoting angiogenesis, preventing cardiomyocyte apoptosis and reducing adverse remodelling. It may be that future potential remedies, such as statins, that enhance the function of endothelial progenitor cells may play an important role in improving stem cell survival and function. One of the ways of improving cell survival may be achieved by using viral vectors encoding multiple cytoprotective genes that act on different cell death and apoptotic pathways, or by preconditioning the stem cells with cytokines that result in improved cell engraftment.

Another important issue is the timing of cell administration post-MI. Although animal studies have supported early administration of stem cells post-infarction, in humans the benefits of this therapy were greater when administered $>4$ days after reperfusion (based on available evidence). Furthermore, given the seemingly small improvements that these trials have shown, the costeffectiveness of cell therapy will also need to be addressed.

Two ongoing randomised controlled trials (TIME and late TIME studies) may help us understand whether the timing of cell administration plays an important role. The TIME study (Clinicaltrials.gov NCT00684021) is a trial designed to assess the effect of timing (3 versus 7 days) of BMMNC administration versus placebo in patients with acute MI. The LATE TIME study (Clinicaltrials.gov NCT00684060) will assess the effect of BMMNC administration 2 to 3 weeks after a MI.

\section{Future cells}

Animal and human studies have clearly shown that stem cell engraftment into the myocardium is associated with improvement in cardiac function; however, the quest for the optimal population of cells remains a challenge $[85,86]$. Embryonic stem cells are able to transform into cardiomyocytes and can replicate indefinitely, although ethical issues - their potential to form teratomas and the need for immunosuppressive therapy - have hindered their use in clinical trials. Furthermore, one of the major limitations of adult stem cells, including skeletal myoblasts and bone marrow-derived stem cells, is their limited ability to cross their lineage boundaries. 
Fat tissue-derived multipotent stem cells [87], multipotential cells from bone marrow or skeletal muscle $[88,89]$, somatic stem cells from placental cord blood [90], and cardiac-resident progenitor cells [32,91] all show promising pre-clinical and some clinical applications.

Ultimately, cells that more closely resemble embryonic stem cells in their regenerative potential without the ethical issues provide an important future direction. A cell type that comes close, and is on the horizon of being tested for potential clinical application, is the inducible pluripotent stem cell (iPSC). iPSCs can be generated from adult human somatic cells by retroviral transduction [92], have similar differentiation potential and may provide an alternative to pluripotent embryonic stem cells.

\section{The future of bone marrow stem cells}

For the time being, it is important to establish whether the simple unfractionated bone marrow cell approach has clinical benefit, given the large number of studies that have been performed using this cell type without providing a clear answer. Meta-analysis suggests a positive effect on surrogate cardiac end-points in studies using BMMNCs to treat AMI. There is now a need to perform a large scale clinical trial using clinical hard end-points such as mortality to establish whether the positive effects seen on surrogate end-points can indeed translate to meaningful clinical benefits.

\section{Abbreviations}

AMI, acute myocardial infarction; ASTAMI, Autologous Stem-Cell Transplantation in Acute Myocardial Infarction; BMMNC, bone marrowderived mononuclear cell; BOOST, Bone Marrow Transfer to Enhance STElevation Infarct Regeneration; EF, ejection fraction; LV, left ventricular; LVEF, left ventricular ejection fraction; $\mathrm{MI}$, myocardial infarction; $\mathrm{PCl}$, percutaneous coronary intervention; REPAIR-AMI, Intracoronary bone marrow derived progenitor cells in acute infarction; SDF, stromal-cell-derived factor.

\section{Competing interests}

The authors have no relevant affiliations or financial involvement with any organisation or entity with a financial interest in or financial conflict with the subject matter or materials discussed in the manuscript. This includes employment, consultancies, honoraria, stock ownership or options, expert testimony, grants or patents received or pending, or royalties. No writing assistance was utilized in the production of this manuscript.

\section{Acknowledgements}

This work forms part of the research themes contributing to the translational research portfolio of Barts and the London Cardiovascular Biomedical Research Unit, which is supported and funded by the National Institute of Health Research.

\section{Author details}

'Department of Cardiology, London Chest Hospital, Bonner Road, London E2 9JX, UK. ²Department of Cardiology, London Chest Hospital, Queen Mary University of London, Barts and the London NHS Trust, Bonner Road, London E2 9JX, UK.

Published: 17 January 2012

\section{References}

1. Pfeffer M, John J, McMurray M, Velazquez E, Rouleau J: Valsartan, captopril, or both in myocardial infarction complicated by heart failure, left ventricular dysfunction, or both. N Eng J Med 2003, 349:1893-1906.

2. Braunwald E: Cardiovascular medicine at the turn of the millennium: triumphs, concerns, and opportunities. N Eng J Med 1997, 337:1360-1369.

3. Mathur A, Martin JF: Stem cells and repair of the heart. Lancet 2004, 364:183-192

4. Yeh TH, Zhang S, Wu H: Transdifferentiation of human peripheral blood CD34+ enriched cell population into cardiomyocytes, endothelial cell and smooth muscle cells in vivo. Circulation 2003, 108:2070-2073.

5. Badorff C: Transdifferentiation of blood-derived human adult endothelial progenitor cells into functionally active cardiomyocytes. Circulation 2003, 107:1024-1032.

6. Kawada H, Fujita J, Kinjo K: Non-haematopoietic mesenchymal stem cells can be mobilized and differentiate into cardiomyocytes after myocardial infarction. Blood 2004, 104:3581-3587.

7. Orlic D: Mobilized bone marrow cells repair the infarcted heart, improving function and survival. Proc Natl Acad Sci U S A 2001, 98:10344-10349.

8. Orlic D, Kajstrua J, Chimenti S: Bone marrow cells regenerate infracted myocardium. Nature 2001, 410:701-705.

9. Strauer B, Brehm M, Zeus T: Repair of infracted myocardium by autologous intracoronary mononuclear bone marrow cell transplantation in humans. Circulation 2002, 106:1913-1918.

10. Assmus $B$, Schächinger $\vee$, Teupe $C$ : Transplantation of progenitor cells and regeneration enhancement in acute myocardial infarction (TOPCARE-AMI). Circulation 2002, 106:3009-3017.

11. Schächinger $V$, Assmus $B$, Britten M: Transplantation of progenitor cells and regeneration enhancement in acute myocardial infarction: Final one year results of the TOPCARE-AMI trial. J Am College Cardiol 2004, 44:1690-1699.

12. Lunde $K$, Solheim $S$, Aakhus $S$, Arnesen $H$, Abdelnoor M, Egeland T, Endresen K, llebekk A, Mangschau A, Fjeld JG, Smith HJ, Taraldsrud E, Grøgaard HK, Bjørnerheim R, Brekke M, Müller C, Hopp E, Ragnarsson A, Brinchmann JE, Forfang K: Intracoronary injection of mononuclear bone marrow cells in acute myocardial infarction. N Eng J Med 2006, 355:1199-1209.

13. Seeger FH, Tonn T, Krzossok N, Zeiher AM, Dimmeler S: Cell isolation procedures matter: a comparison of different isolation protocols of bone marrow mononuclear cells used for cell therapy in patients with acute myocardial infarction. Eur Heart J 2007, 28:766-772.

14. Wollert K, Meyer G, Joachim L: Intracoronary autologous bone-marrow cell transfer after myocardial infarction: the BOOST randomised controlled clinical trial. Lancet 2004, 364:141-148.

15. Yousef M, Schannwell CM, Kostering M, Zeus T, Brehm M, Strauer BE: The BALANCE Study: clinical benefit and long-term outcome after intracoronary autologous bone marrow cell transplantation in patients with acute myocardial infarction. J Am Coll Cardiol 2009, 53:2262-2269.

16. Ge J, Qian J: Efficacy of emergent transcatheter transplantation of stem cells for treatment of acute myocardial infarction (TCT-STAMI). Heart 2006 92:1764-1767.

17. Schächinger $V$, Erbs S, Elsässer A: REPAIR-AMI investigators. Intracoronary bone marrow derived progenitor cells in acute infarction. N Eng J Med 2006, 355:1210-1221.

18. Schächinger V, Erbs S, Elsässer A, Haberbosch W, Hambrecht R, Hölschermann H, Yu J, Corti R, Mathey DG, Hamm CW, SüselbeckT, Werner N, Haase J, Neuzner J, Germing A, Mark B, Assmus B, Tonn T, Dimmeler S, Zeiher AM; REPAIR-AMI Investigators: Improved clinical outcome after intracoronary administration of bone-marrow-derived progenitor cells in acute myocardial infarction: final 1-year results of the REPAIR-AMI trial. Eur Heart J 2006, 27:2775-2783

19. Janssens S, Dubois C, Bogaert J: Autologous bone marrow derived stem cell transfer in patients with ST-segment elevation myocardial infarction: double blind randomised controlled trial. Lancet 2006, 367:113-121.

20. Tendera M, Wojakowski W, Ruzyłło W, Chojnowska L, Kepka C, Tracz W, Musiałek P, Piwowarska W, Nessler J, Buszman P, Grajek S, Breborowicz P, Majka $M$, Ratajczak MZ; REGENT Investigators: Intracoronary infusion of bone marrow-derived selected CD34+CXCR4+ cells and non-selected mononuclear cells in patients with acute STEMI and reduced left ventricular ejection fraction: results of randomized, multicentre Myocardial Regeneration by Intracoronary Infusion of Selected Population of Stem Cells in Acute Myocardial Infarction (REGENT) Trial. Eur Heart $J$ 2009, 30:1313-1321.

21. Hirsch A, Nijveldt R, van der Vleuten PA, Tijssen JG, van der Giessen WJ, Tio RA Waltenberger J, ten Berg JM, Doevendans PA, Aengevaeren WR, Zwaginga JJ, Biemond BJ, van Rossum AC, Piek JJ, Zijlstra F; HEBE Investigators: 
Intracoronary infusion of mononuclear cells from bone marrow or peripheral blood compared with standard therapy in patients after acute myocardial infarction treated by primary percutaneous coronary intervention: results of the randomized controlled HEBE trial. Eur Heart J 2011, 32:1736-1747.

22. Martin-Rendon E, Brunskill SJ, Hyde CJ, Stanworth SJ, Mathur A, Watt SM: Autologous bone marrow stem cells to treat acute myocardial infarction: a systematic review. Eur Heart J 2008, 29:1807-1818.

23. Lipinski JM, Giuseppe GL, Zoccai B, Abbate A, Khianey R: Impact of intracoronary cell therapy on left ventricular function in the setting of acute myocardial infarction. J Am College Cardiol 2007, 50:1761-1767.

24. Abdel-Latif A, Bolli R, Tleyjeh IM, Montori VM, Perin EC, Hornung CA, ZubaSurma EK, Al-Mallah M, Dawn B: Adult bone marrow-derived cells for cardiac repair: a systematic review and meta-analysis. Arch Intern Med 2007, 167:989-997.

25. Reffelmann T, Konemann S, Kloner RA: Promise of blood- and bone marrowderived stem cell transplantation for functional cardiac repair: putting it in perspective with existing therapy. J Am Coll Cardio/ 2009, 53:305-308.

26. Stone GW, Grines CL, Cox DA, Garcia E, Tcheng JE, Griffin JJ, Guagliumi G, Stuckey T, Turco M, Carroll JD, Rutherford BD, Lansky AJ; Controlled Abciximab and Device Investigation to Lower Late Angioplasty Complications (CADILLAC) Investigators: Comparison of angioplasty with stenting, with or without abciximab, in acute myocardial infarction. NEngl J Med 2002, 346:957-966.

27. Montalescot G, Barragan P, Wittenberg O, Ecollan P, Elhadad S, Villain P, Boulenc JM, Morice MC, Maillard L, Pansiéri M, Choussat R, Pinton P; ADMIRAL Investigators. Abciximab before Direct Angioplasty and Stenting in Myocardial Infarction Regarding Acute and Long-Term Follow-up: Platelet glycoprotein Ilb/Illa inhibition with coronary stenting for acute myocardial infarction. N Engl J Med 2001, 344:1895-1903.

28. Curtis JP, Sokol SI, Wang Y, Rathore SS, Ko DT, Jadbabaie F, Portnay EL, Marshalko SJ, Radford MJ, Krumholz HM: The association of left ventricular ejection fraction, mortality, and cause of death in stable outpatients with heart failure. J Am Coll Cardiol 2003, 42:736-742.

29. Tribouilloy C, Rusinaru D, Mahjoub H, Soulière V, Lévy F, Peltier M, Slama M, Massy Z: Prognosis of heart failure with preserved ejection fraction: a 5 year prospective population-based study. Eur Heart J 2008, 29:339-347.

30. Sharif F, Bartunek J, Vanderheyden M: Adult stem cells in the treatment of acute myocardial infarction. Catheter Cardiovasc Interv 2011, 77:72-83.

31. Lai VK, Ang KL, Rathbone W, Harvey NJ, Galinanes M: Randomized controlled trial on the cardioprotective effect of bone marrow cells in patients undergoing coronary bypass graft surgery. Eur Heart J 2009, 30:2354-2359.

32. Oh $\mathrm{H}$ : Cardiac progenitor cells from adult myocardium: homing, differentiation, and fusion after infarction. Proc Natl Acad Sci U S A 2003, 100:12313-12318

33. Murry C, Soonpaa M, Reinecke $\mathrm{H}$ : Haematopoietic stem cells do not transdifferentiate into cardiac myocytes in myocardial infarcts. Nature 2004, 428:664-668

34. Balsam L, Wagers A, Christensen J: Haematopoietic stem cells adopt mature haematopoietic fates in ischaemic myocardium. Nature 2004, 428:668-673.

35. Caplan Al, Dennis JE: Mesenchymal stem cells as trophic mediators. J Cell Biochem 2006, 98:1076-1084.

36. Kinnaird T, Stabile E, Burnett MS, Lee CW, Barr S, Fuchs S, Epstein SE: Marrowderived stromal cells express genes encoding a broad spectrum of arteriogenic cytokines and promote in vitro and in vivo arteriogenesis through paracrine mechanisms. Circ Res 2004, 94:678-685.

37. Takahashi M, Li TS, Suzuki R, Kobayashi T, Ito H, Ikeda Y, Matsuzaki M, Hamano $\mathrm{K}$ : Cytokines produced by bone marrow cells can contribute to functional improvement of the infarcted heart by protecting cardiomyocytes from ischemic injury. Am J Physiol Heart Circ Physiol 2006, 291:H886-H893.

38. Kubal C, Sheth K, Nadal-Ginard B, Galinanes M: Bone marrow cells have a potent anti-ischemic effect against myocardial cell death in humans. J Thorac Cardiovasc Surg 2006, 132:1112-1118.

39. Nelissen-Vrancken H, Debets J, Snoeckx L, Daemen M, Smits J: Time-related normalization of maximal coronary flow in isolated perfused hearts of rats with myocardial infarction. Circulation 1996, 93:349-355.

40. Takahashi T, Kalka C, Masuda H: Ischemia- and cytokine-induced mobilization of bone marrow-derived endothelial progenitor cells for neovascularization. Nat Med 1999, 5:434-438.

41. Kalka C, Masuda H, Takahashi T: Transplantation of ex vivo expanded endothelial progenitor cells for therapeutic neovascularization. Proc Nat
Acad Sci U SA 2000, 97:3422-3427.

42. Folkman J: Therapeutic angiogenesis in ischemic limbs. Circulation 1998 97:1108-1110

43. Asahara T: Isolation of putative progenitor cells for endothelial angiogenesis. Science 1997, 275:964-967.

44. Isner J, Asahara T: Angiogenesis and vasculogenesis as therapeutic strategies for postnatal neovascularization. J Clin Invest 1999, 103:1231-1236.

45. Dowell JD, Rubart M, Pasumarthi KBS, Soonpaa MH, Field LJ: Myocyte and myogenic stem cell transplantation in the heart. Cardiovasc Res 2003, 58:336-350.

46. Kocher A: Neovascularization of ischemic myocardium by human bonemarrow-derived angioblasts prevents cardiomyocyte apoptosis, reduces remodeling and improves cardiac function. Nat Med 2001, 7:430-436

47. Kawamoto A, Gwon HC, Iwaguro H, Yamaguchi II, Uchida S, Masuda H, Silver M, Ma H, Kearney M, Isner JM, Asahara T: Therapeutic potential of ex vivo expanded endothelial progenitor cells for myocardial ischemia. Circulation 2001, 103:634-637.

48. Urbich C, Heeschen C, Aicher A, Dembach E, Zeiher AM, Dimmeler S: Relevance of monocytic features for neovascularization capacity of circulating endothelial progenitor cells. Circulation 2003, 108:2511-2516.

49. Aicher A, Heeschen C, Mildner-Rihm C, Urbich C, Ihling C, Technau-Ihling K, Zeiher AM, Dimmeler S: Essential role of endothelial nitric oxide synthase for mobilization of stem and progenitor cells. Nat Med 2003, 9:1370-1376.

50. Fuchs S, Baffour R, Zhou Y: Transendocardial delivery of autologous bone marrow enhances collateral perfusion and regional function in pigs with chronic experimental myocardial ischaemia. J Am College Cardiol 2001, 37:1726-1732.

51. Hamano K, LiT, Kobayashi T: Therapeutic angiogenesis induced by local autologous bone marrow cell implantation. Ann Thoracic Surg 2002, 73:1210-1215.

52. Kamihata $H$, Matsubara $H$, Nishiue T: Improvement of collateral perfusion and regional function by implantation of peripheral blood mononuclear cells into ischemic hibernating myocardium. Arterioscler Thromb Vasc Biol 2002, 22:1804-1810.

53. Kamihata $\mathrm{H}$, Matsubara $\mathrm{H}$, Nishiue $\mathrm{T}$ : Implantation of bone marrow mononuclear cells into ischemic myocardium enhances collateral perfusion and regional function via side supply of angioblasts, angiogenic ligands, and cytokines. Circulation 2001, 104:1046-1052

54. Jackson K: Regeneration of ischemic cardiac muscle and vascular endothelium by adult stem cells. J Clin Invest 2001, 107:1395-1402.

55. Rehman J, Li J, Orschell CM, March KL: Peripheral blood "endothelial progenitor cells" are derived from monocyte/macrophages and secrete angiogenic growth factors. Circulation 2003, 107:1164-1169.

56. Shintani S, Murohara T, Ikeda H: Mobilization of endothelial progenitor cells in patients with acute myocardial infarction. Circulation 2001, 103:2776-2779.

57. Iwaguro H, Yamaguchi J, Kalka C: Endothelial progenitor cell vascular endothelial growth factor gene transfer for vascular regeneration. Circulation 2002, 105:732-738

58. Perin E: Transendocardial, autologous bone marrow cell transplantation for severe, chronic ischemic heart failure. Circulation 2003, 107:2294-2302.

59. Beauchamp J, Morgan J, Pagel C, Partridge T: Dynamics of myoblast transplantation reveal a discrete minority of precursors with stem cell-like properties as the myogenic source. J Cell Biol 1999, 144:1113-1122.

60. Papayannopoulou T: Bone marrow homing: the players, the playfield, and their evolving roles. Curr Opin Hematol 2003, 10:214-219.

61. Aicher A: Assessment of the tissue distribution of transplanted human endothelial progenitor cells by radioactive labeling. Circulation 2003, 107:2134-2139.

62. De Falco E: Sdf-1 involvement in endothelial phenotype and ischemiainduced recruitment of bone marrow progenitor cells. Blood 2004, 104:3472-3482.

63. Chavakis $\mathrm{E}$ : Role of $\mathrm{b} 2$-integrins for homing and neovascularization capacity of endothelial progenitor cells. J Exp Med 2005, 201:63-72.

64. Vajkoczy P: Multistep nature of microvascular recruitment of ex vivoexpanded embryonic endothelial progenitor cells during tumor angiogenesis. J Exp Med 2003, 197:1755-1765.

65. Askari A: Effect of stromal-cell-derived factor 1 on stem-cell homing and tissue regeneration in ischaemic cardiomyopathy. Lancet 2003, 362:697-703 
66. Yamaguchi J: Stromal cell-derived factor-1 effects on ex vivo expanded endothelial progenitor cell recruitment for ischemic neovascularization. Circulation 2003, 107:1322-1328.

67. Scaffidi P, Misteli T, Bianchi M: Release of chromatin protein hmgb1 by necrotic cells triggers inflammation. Nature 2002, 418:191-195.

68. Hristov M, Zernecke A, Bidzhekov K, Liehn EA, Shagdarsuren E, Ludwig A, Weber C: Importance of CXC chemokine receptor 2 in the homing of human peripheral blood endothelial progenitor cells to sites of arterial injury. Circ Res 2007, 100:590-597.

69. Levesque JP, Hendy J, Takamatsu Y, Simmons PJ, Bendall LJ: Disruption of the CXCR4/CXCL12 chemotactic interaction during hematopoietic stem cell mobilization induced by GCSF or cyclophosphamide. J Clin Invest 2003, 111:187-196.

70. Petit I, Szyper-Kravitz M, Nagler A, Lahav M, Peled A, Habler L, Ponomaryov T, Taichman RS, Arenzana-Seisdedos F, Fujii N, Sandbank J, Zipori D, Lapidot T: G-CSF induces stem cell mobilization by decreasing bone marrow SDF-1 and up-regulating CXCR4. Nat Immuno/ 2002, 3:687-694.

71. Yamaguchi J, Kusano KF, Masuo O, Kawamoto A, Silver M, Murasawa S, BoschMarce M, Masuda H, Losordo DW, Isner JM, Asahara T: Stromal cell-derived factor-1 effects on ex vivo expanded endothelial progenitor cell recruitment for ischemic neovascularization. Circulation 2003, 107:1322-1328.

72. Bartunek J, Dimmeler S, Drexler H, Fernández-Avilés F, Galinanes M, Janssens S, Martin J, Mathur A, Menasche P, Priori S, Strauer B, Tendera M, Wijns W Zeiher A; task force of the European Society of Cardiology: The consensus of the task force of the European Society of Cardiology concerning the clinical investigation of the use of autologous adult stem cells for repair of the heart. Eur Heart J 2006, 27:1338-1340.

73. Ramalho-Santos M, Yoon S, Matsuzaki Y, Mulligan R, Melton D: "Stemness": transcriptional profiling of embryonic and adult stem cells. Science 2002, 298:597-600.

74. Jiang S, Haider HK, Idris NM, Salim A, Ashraf M: Supportive interaction between cell survival signaling and angiocompetent factors enhances donor cell survival and promotes angiomyogenesis for cardiac repair. Circ Res 2006, 99:776-784

75. Norol F, Bonnet N, Peinnequin A, Chretien F, Legrand R, Isnard R, Herodin F, Baillou C, Delache B, Negre D, Klatzmann D, Vernant JP, Lemoine FM: GFP-transduced CD34+ and Lin- CD34- hematopoietic stem cells did not adopt a cardiac phenotype in a nonhuman primate model of myocardial infarct. Exp Hematol 2007, 35:653-661.

76. Nakamura Y, Wang X, Xu C, Asakura A, Yoshiyama M, From AH, Zhang J: Xenotransplantation of long-term-cultured swine bone marrow-derived mesenchymal stem cells. Stem Cells 2007, 25:612-620.

77. Heeschen C: Profoundly reduced neovascularization capacity of bone marrow mononuclear cells derived from patients with chronic ischemic heart disease. Circulation 2004, 109:1615-1622.

78. Vasa M: Number and migratory activity of circulating endothelial progenitor cells inversely correlate with risk factors for coronary artery disease. Circ Res 2001, 89:E1-E7.

79. Hill J: Circulating endothelial progenitor cells, vascular function, and cardiovascular risk. N Eng J Med 2003, 348:593-600.

80. Edelberg J, Tang L, Hattori K, Lyden D, Rafii S: Young adult bone marrowderived endothelial precursor cells restore aging-impaired cardiac angiogenic function. Circ Res 2002, 90:E89-E93.

81. Torella D: Cardiac stem cell and myocyte aging, heart failure, and insulinlike growth factor-1 overexpression. Circ Res 2004, 94:514-524.

82. Assmus B: Hmg-coa reductase inhibitors reduce senescence and increase proliferation of endothelial progenitor cells via regulation of cell cycle regulatory genes. Circ Res 2003, 92:1049-1055.

83. Spyridopoulos I: Statins enhance migratory capacity by upregulation of the telomere repeat-binding factor trf2 in endothelial progenitor cells. Circulation 2004, 110:3136-3142.

84. Hong SJ, Choi SC, Kim JS, Shim WJ, Park SM, Ahn CM, Park JH, Kim YH, Lim DS: Low-dose versus moderate-dose atorvastatin after acute myocardial infarction: 8-month effects on coronary flow reserve and angiogenic cell mobilisation. Heart 2010, 96:756-764.

85. Smits AM, van VP, Hassink RJ, Goumans MJ, Doevendans PA: The role of stem cells in cardiac regeneration. J Cell Mol Med 2005, 9:25-36.

86. Davani S, Deschaseaux F, Chalmers D, Tiberghien P, Kantelip JP: Can stem cells mend a broken heart? Cardiovasc Res 2005, 65:305-316.

87. Planat-Benard V: Spontaneous cardiomyocyte differentiation from adipose tissue stroma cells. Circ Res 2004, 94:223-229.

88. Jiang Y: Multipotent progenitor cells can be isolated from postnatal murine bone marrow, muscle, and brain. Exp Hematol 2002, 30:896-904.

89. Jiang Y: Pluripotency of mesenchymal stem cells derived from adult marrow. Nature 2002, 418:41-49.

90. Kogler $\mathrm{G}$ : A new human somatic stem cell from placental cord blood with intrinsic pluripotent differentiation potential. J Exp Med 2004, 200:123-135

91. Beltrami A: Adult cardiac stem cells are multipotent and support myocardial regeneration. Cell 2003, 114:763-776.

92. Takahashi K, Tanabe K, Ohnuki M, Narita M, Ichisaka T, Tomoda K, Yamanaka S Induction of pluripotent stem cells from adult human fibroblasts by defined factors. Cell 2007, 131:861-872.

93. Meluzin J, Mayer J, Groch L: Autologous transplantation of mononuclear bone marrow cells in patients with acute myocardial infarction: The effect of the dose of transplanted cells on myocardial function. Am Heart J 2006, 152:e9-e15.

94. Fernández-Avilés F, San Román JA, García-Frade J, Fernández ME, Peñarrubia MJ, de la Fuente L, Gómez-Bueno M, Cantalapiedra A, Fernández J, Gutierrez O, Sánchez PL, Hernández C, Sanz R, García-Sancho J, Sánchez A: Experimental and clinical regenerative capability of human bone marrow cells after myocardial infarction. Circ Res 2004, 95:742-748.

95. De Lezo J, Herrera C, Pan M: Regenerative therapy in patients with a revascularized acute anterior myocardial infarction and depressed ventricular function. Rev Esp Cardio/ 2007, 60:357-365.

96. Zhan-quan L, Ming Z: The clinical study of autologous peripheral blood stem cell transplantation by intracoronary infusion in patients with acute myocardial infarction. Int J Cardio/ 2007, 115:52-56.

97. Lipiec P, Pakula M, Plewka M: Impact of intracoronary injection of mononuclear bone marrow cells in acute myocardial infarction on left ventricular perfusion and function: a 6-month follow-up gated mTc-MIBI single-photon emission computed tomography study. Eur J Nuclear Mol Imaging 2009, 36:587-593.

98. Huikuri H, Kervinen K, Niemelä M: Effects of intracoronary injection of mononuclear bone marrow cells on left ventricular function, arrhythmia risk profile, and restonosis after thrombolytic therapy of acute myocardial infarction. Eur Heart J 2008, 29:2723-2732.

99. Kang H, Kim H, Zhang S, Park K, Cho H, Koo B: Effects of intracoronary infusion of peripheral blood stem-cells mobilised with granulocytecolony stimulating factor on left ventricular systolic function and restenosis after coronary stenting in myocardial infarction: the MAGIC cell randomised clinical trial. Lancet 2004, 363:751-756.

100. Bartunek J, Vanderheyden M, Vandekerckhove B: Intracoronary injection of CD133 positive enriched bone marrow progenitor cells promotes cardiac recovery after recent myocardial infarction: feasibility and safety. Circulation 2005, 112:|-178-I-183.

101. Chen SL, Fang WW, Ye F, Liu YH, Qian J, Shan SJ, Zhang JJ, Chunhua RZ, Liao LM, Lin S, Sun JP: Effect on left ventricular function of intracoronary transplantation of autologous bone marrow mesenchymal stem cell in patients with acute myocardial infarction. Am J Cardiol 2004, 94:92-95.

doi:10.1186/scrt93

Cite this article as: Arnous $\mathrm{S}$, et al:: Bone marrow mononuclear cells and

acute myocardial infarction. Stem Cell Research \& Therapy 2012, 3:2. 